\title{
Pathogenicity of Phytophthora isolates originating from several woody hosts in Bulgaria and Poland
}

\author{
Aneta B. Lyubenova ${ }^{1}$, Justyna A. Nowakowska ${ }^{2}$ Katarzyna Sikora $^{3} \bowtie$, Kaloyan Kostov $^{1}$, \\ Małgorzata Borys ${ }^{2}$, Slavtcho B. Slavov ${ }^{1}$, Tomasz Oszako ${ }^{4}$ \\ ${ }^{1}$ AgroBioInstitute, Agricultural Academy, Biotic Stress group, Dragan Tsankov 8, Sofia, Bulgaria \\ ${ }^{2}$ Forest Research Institute, Laboratory of Molecular Biology, Sękocin Stary, Braci Leśnej 3, 05-090 Raszyn, Poland \\ ${ }^{3}$ Forest Research Institute, Department of Forest Protection, Sękocin Stary, Braci Leśnej 3, 05-090 Raszyn, Poland, \\ phone: +48 22 7150548, e-mail: K.Sikora@ibles.waw.pl \\ ${ }^{4}$ Technical University of Białystok, Forest Faculty, Piłsudskiego 8, 17-200 Hajnówka, Poland
}

\section{Abstract}

Our aim was to examine the virulence of eight Phytophthora isolates belonging to three species (Phytophthora cryptogea, Phytophthora plurivora and Phytophthora quercina) obtained from diverse European ecosystems (in Bulgaria, Poland and Germany) towards three forest tree hosts - English oak (Quercus robur L.), Turkey oak (Quercus cerris L.) and European beech (Fagus sylvatica L.).

All plants grown from seeds in a greenhouse conditions were artificially inoculated under the stem bark with Phytophthora cultures. The tested isolates turned to be more aggressive to Turkey oaks than to English oak trees. In case of European beech, the isolates of $P$. cryptogea and P. plurivora exposed various virulence. The potential hazard of the introduced foreign isolates for the oak and beech forests in Poland and Bulgaria is discussed. Amongst the tested isolates, P. quercina P290 from German highly infected Bulgarian Turkey oaks; therefore, its negative potential impact on Bulgarian oak forests could be considered as high (if unintentionally introduced). Also, two Bulgarian isolates belonging to P. cryptogea and P. plurivora are risky for Polish beech forests, if exposed to the pathogen. The observed pathogenicity of the tested Phytophthora species proved their potential as important contributors to decline of valuable forest ecosystems dominated by oaks (Q. robur and Q. cerris) or beech (F. sylvatica), in both Poland and Bulgaria. We found that investigated Phytophthora pathogens could develop in the living plant stem tissues without causing any disease symptoms, which is another demonstration that phytosanitary control by simple observation of plant material is not effective.

\section{KeY WORDS}

decline, Fagus sylvatica, Quercus cerris, Quercus robur, Phytophthora, virulence 


\section{INTRODUCTION}

Alien fungal and fungal-like pathogens are considered to be one of the main causes of emerging infectious disease in forests over the past four decades (Santini et al. 2013). The oomycete genus Phytophthora comprises a large number of plant pathogens that cause significant damage to various natural and agricultural ecosystems in altered climatic zones (Callaghan and Guest 2015). Bulgaria is situated in south-eastern Europe and encompasses a wide range of environments. Since the country joined the European market, the risk of introduction and establishment of alien species is undoubtedly grown. Apart from the well-known Phytophthora pathogens occurring on the agricultural crops (Nakova 2010; Ilieva et al. 1995), there is no sufficient information available for the natural ecosystems in Bulgaria, except the report of ink disease on chestnut (Panov and Bulgariev 1982). The above records show that Phytophthora species are widespread, abundant, very diverse and poorly investigated, especially in undisturbed forest ecosystems. During the past decades, and in particular after alternating dry and wet years, an increasing number of European beech (Fagus sylvatica L.) stands across Europe have demonstrated symptoms typical for Phytophthora disease (Jung 2009). Poland is situated in central Europe, and analogically same beech and oak species could be under threat from pathogenic Phytophthora spp.

The development of DNA-based technologies has revealed much broader and more complex diversity than previously recognised and has led to the recent description of many new species (Callaghan and Guest 2015). The soil-borne species Phytophthora quercina T. Jung appears to be strongly involved in the European oak decline phenomenon (Jönsson et al. 2003). The species pathogenicity has been studied only on the fine roots of Central European oaks (Jung et al. 1999). Phytophthora plurivora T. Jung \& T.I. Burgess has most likely been spread from Europe in the rest of the world with the nursery trade, that is, through diseased plants for plantings (Schoebel et al. 2014). The international trade has allowed pathogens to colonise new environments and/ or hosts, resulting in the growth of $P$. plurivora population, which is currently frequently occurring in nurseries and forest stands in Poland (Orlikowski et al. 1995, 2004; Oszako et al. 2007).
The oak forests of northern and central Europe are dominated by the deciduous forest species of Quercus robur and Quercus petraea (Matt.) Liebl. These two species are very important in Poland from both ecological and economical point of view. The most beautiful oak forests with unique wood characteristics, such as narrow annual increments, are growing in the Krotoszyn Plateau (close to Poznań in western Poland) and are very much appreciated by wood industry. In contrast, Quercus cerris is a part of flora of oak woodlands in southern and Mediterranean Europe containing evergreen oak species, including the territory of Bulgaria. The present work aims to evaluate the variation in the pathogenicity and virulence of Phytophthora isolates (Phytophthora cryptogea, $P$. plurivora and $P$. quercina) obtained from Polish and Bulgarian beech and oak stands.

\section{MATERIAL AND MEthodS}

\section{Phytophthora isolates}

Eight Phytophthora isolates were used in this study. Six of them belonged to species P. cryptogea and P. plurivora and were obtained from the rhizosphere of damaged trees growing in various ecosystems in Bulgaria. They were identified on the basis of morphology and sequence similarity to Phytophthora sequences deposited in the NCBI GenBank data base (Lyubenova et al. 2016). Two P. quercina isolates were added in the experiments, both of them isolated from $Q$. robur, one from Poland and one from Germany (Tab. 1). Species identification of Polish isolates was performed as described by Trzewik et al. (2015).

Prior to the use of isolates in inoculation tests, they were grown on $10 \%$ vegetable juice agar media ( $100 \mathrm{~g}$ of vegetable juice 'Gemuse saft Alnatura', $3 \mathrm{~g}$ of $\mathrm{CaCO}_{3}$, $10 \mathrm{~g}$ of plant agar (Duchefa Biochemie) and $900 \mathrm{ml}$ of distilled water) in the dark at $25^{\circ} \mathrm{C}$ for a period of three to eight days, depending on the intensity of mycelial growth of particular species.

\section{Plant material}

Three forest tree species were tested as host plants in the pathogenicity tests: 3-month-old Turkey oaks (Q. cerris L.) of the Bulgarian origin, 5-month-old English oaks (Q. robur L.) and European beeches (F. sylvatica L.). The last two species were originated from Po- 
Table 1. Phytophthora isolates used in the study, their hosts and origin of the isolate

\begin{tabular}{|l|l|l|}
\hline \multicolumn{1}{|c|}{ Isolate } & \multicolumn{1}{|c|}{ Host } & \multicolumn{1}{|c|}{ Location } \\
\hline Phytophthora quercina Poland 9 & Quercus robur (L.) & Piaski Forest District, Poland \\
\hline Phytophthora quercina Jung ATCC ${ }^{\circledR}$ MYA 4084 ${ }^{\mathrm{TM}}$ P290 & Quercus robur (L.) & Germany \\
\hline Phytophthora cryptogea Belasica 10/3 & Castanea sativa (Mill.) & Nature Park Belasica, Bulgaria \\
\hline Phytophthora cryptogea Bankya 1/1 & Picea abies (Karst. L.) & Bankya, Bulgaria \\
\hline Phytophthora plurivora Velingrad 1/1 & Alnus incana (L.) & Velingrad, Bulgaria \\
\hline Phytophthora plurivora Tulovo 4/1 & Quercus robur (L.) & Protected area "Tulovska koria” Bulgaria \\
\hline Phytophthora plurivora Tran 2/1 & Alnus glutinosa (L.) & Along the river of Erma, Bulgaria \\
\hline Phytophthora plurivora Tulovo 7/3 & Quercus robur (L.) & Protected area "Tulovska koria” Bulgaria \\
\hline
\end{tabular}

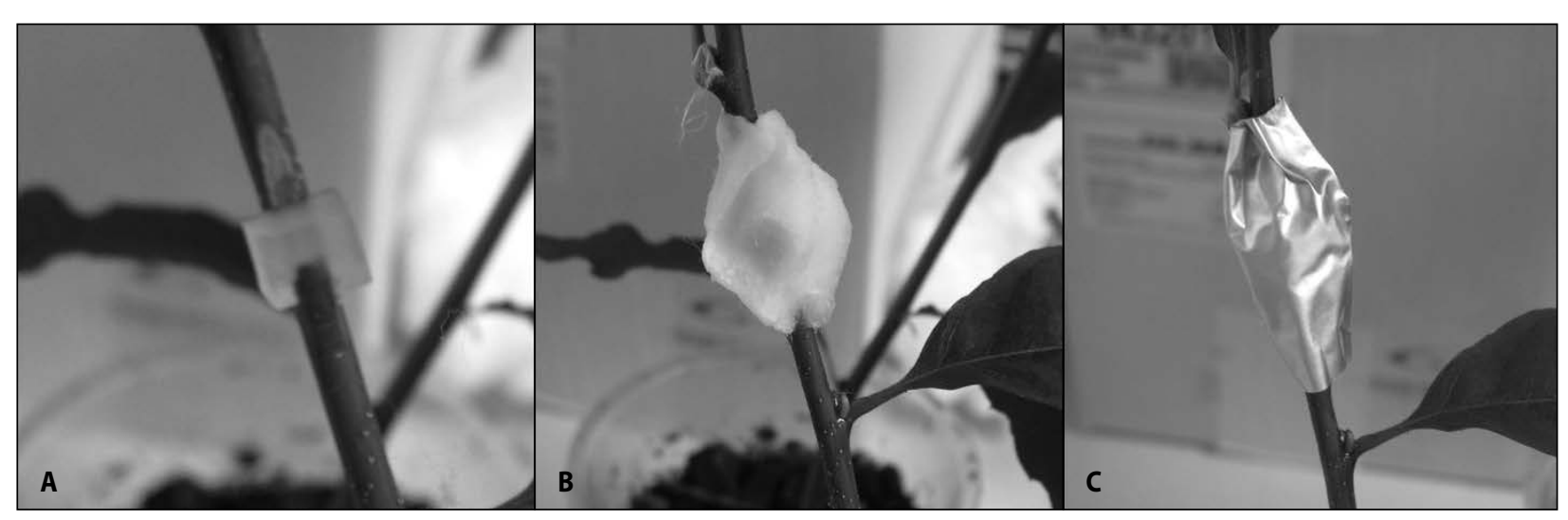

Figure 1. Inoculation procedure of the pathogenicity test with Phytophthora isolates. A - a piece of agar with mycelium placed on the cambium surface of the stem, after cutting the bark with a sterile knife, B - the removed bark was put back and the place was covered with the sterile moist cotton, $\mathrm{C}$ - the inoculation wound was sealed with Parafilm ${ }^{\circledR}$ and covered with aluminium foil

land (Krotoszyn Forest District, Regional Directorate in Poznań). All plants were grown from seeds (in pots containing sterilized soil) in the Forest Research Institute greenhouse under the following conditions: $24^{\circ} \mathrm{C}$ and photoperiod of $16 \mathrm{~h}$ (2000 lux) light and $8 \mathrm{~h}$ dark.

\section{Inoculation procedure}

The plants were inoculated with mycelium of the tested isolates placed under the bark, according to the method developed by Jung and Nechwatal (2008). The plants' bark was cut about $6 \mathrm{~mm}$ along the stem with a sterile knife. A piece of agar (approximately $5 \mathrm{~cm} \times 5 \mathrm{~mm}$ in size) with mycelium was placed on the cambium surface of each stem. Next, the removed bark was put back and the place was covered with sterile moist cotton and then sealed with Parafilm ${ }^{\circledR}$ and covered with aluminium foil (Fig. 1).
The aforementioned plant species were inoculated with the investigated Phytophthora isolates. Each isolate-host combination was replicated eight times. The same number of control plants received only the sterile agar and another eight ones were left uninjured. The inoculated plants were kept under the greenhouse conditions.

Only Q. robur and Q. cerris seedlings were inoculated with $P$. quercina isolates. Those isolates were not applied to inoculate European beeches, as $P$. quercina is a recognised pathogen infecting fine roots of oaks (Jung et al. 1999).

The evaluation of the test was performed three weeks after the inoculation. The length of the observed necrotic lesions longitudinally on the stem of each plant was measured. 


\section{Statistical methods}

The resulting data was analysed using Kruskal-Wallis test. The pairwise comparisons (post-hoc test) was done using Nemenyi-Damico-Wolfe-Dunn test. All statistical analyses were performed with $\mathrm{R}$ (version 3.2.3.).

\section{Re-isolation of pathogens from plant tissues}

To rule out any putative contamination during plant infection experiments and to prove that the symptoms observed on plant stems are caused by organisms used for inoculation, we performed re-isolation of each pathogenic species from infected plant tissues. Several small pieces of the bark taken from the margins of necrotic lesions and healthy tissues next to inoculation wounds of each tested plant were cut, disinfected in $70 \%$ ethanol and placed on 5\% vegetable juice agar media. After few days, the Petri dishes were checked under the light microscope for the occurrence of irregular hyphae, typical for Phytophthora.

\section{Results}

Three weeks after inoculation some necrotic lesions (different length) developed around the inoculation sites on the stems on most of the plants. There were noticeable brown discolorations along the stems of Q. cerris. In the case of $Q$. robur plants, the observed necroses were only limited to the periphery of the inoculation wounds. It was no visible that the pathogen was developing in the plants, although it was successfully re-isolated from the stems, demonstrating their endophytic character. The Phytophthora isolates inoculated in F. sylvatica plants were also successfully re-isolated from stems, regardless of whether necrotic lesions were observed or not.

In general, Phytophthora isolates expressed diverse pathogenicity and aggressiveness depending on the tested host plant species, which were based on the length of necrosis developed in the stem of trees as a result of the inoculation and subsequent infection. There were no symptoms observed (e.g. leaves wilting), which could be assigned only to the specific isolate. The wounds of all inoculated control plants (with sterile agar) were healed, showing obvious release of callus and lack of necrosis. In the control, no necrotic lesions were noticed, so they are not included in the figures and are not further mentioned or discussed.

\section{Infection of English oak (Q. robur) plants}

The necrotic areas on English oak stems developed from the inoculation points when inoculated with P. cryptogea and $P$. plurivora isolates but not in the case of two $P$. quercina ones. Thus both $P$. quercina isolates were not able to infect stems of English oaks. Isolates of $P$. cryptogea and P. plurivora were pathogenic to English oak stems, but no statistically significant difference was found amongst the length of the necrotic lesions (Fig. 2). Nevertheless, all aforementioned isolates provoked necrotic lesions on the stems of English oak seedlings.

\section{Infection of Turkey oak (Q. cerris) plants}

On the contrary to English oaks, the Turkey oaks expressed the higher level of infection after the inoculation with all Phytophthora isolates used in the study (Fig. 3). In this case, both P. quercina isolates caused necrotic stem lesions, but the length of the lesions caused by the isolate P. quercina P290 (German origin) exceeded significantly those caused by the $P$. quercina Poland 9 isolate (Fig. 3).

According to the measurements of necrotic lesions of oak stems, there was no significant difference in susceptibility of Turkey oaks (Q. cerris) inoculated with two $P$. cryptogea isolates, Belasica $10 / 3$ and Bankya $1 / 1$.

In general, amongst the two tested oak species, the Turkey oak seems to be more susceptible to infection by Phytophthora isolates.

\section{Infection of European beech (F. sylvatica) plants}

Bulgarian isolates of $P$. plurivora and $P$. cryptogea expressed their pathogenicity to beech seedlings originated from Poland. Both isolates of P. cryptogea, Belasica 10/3 and Bankya 1/1, were pathogenic, but the first one caused more severe damage to $F$. sylvatica plants. Two from four tested Bulgarian isolates of $P$. plurivora were highly virulent to $F$. sylvatica, and the most aggressive one appears to be $P$. plurivora Tran $2 / 1$. The isolate $P$. plurivora Tulovo $4 / 1$ did not infect $F$. sylvatica seedlings at all (Fig. 4).

P. cryptogea isolates used in the experiments are of Bulgarian origin, obtained from plant species other than those used in the experiment on pathogenicity (Tab. 1). Both isolates of $P$. cryptogea proved to be equally aggressive to $Q$. cerris and $Q$. robur. It is rather obvious that both Bulgarian isolates are much more aggressive 


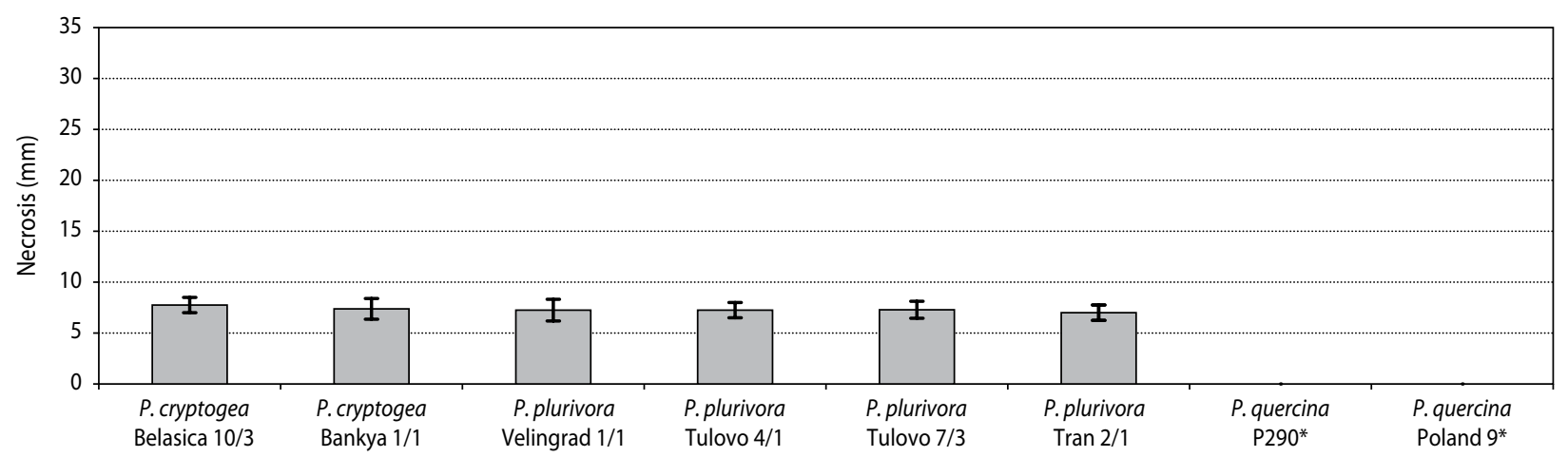

Phytophthora isolate

Figure 2. Mean length of necrosis caused by Phytophthora isolates on English oak (Q. robur) plants

* - statistically significant at $p=0.05$.

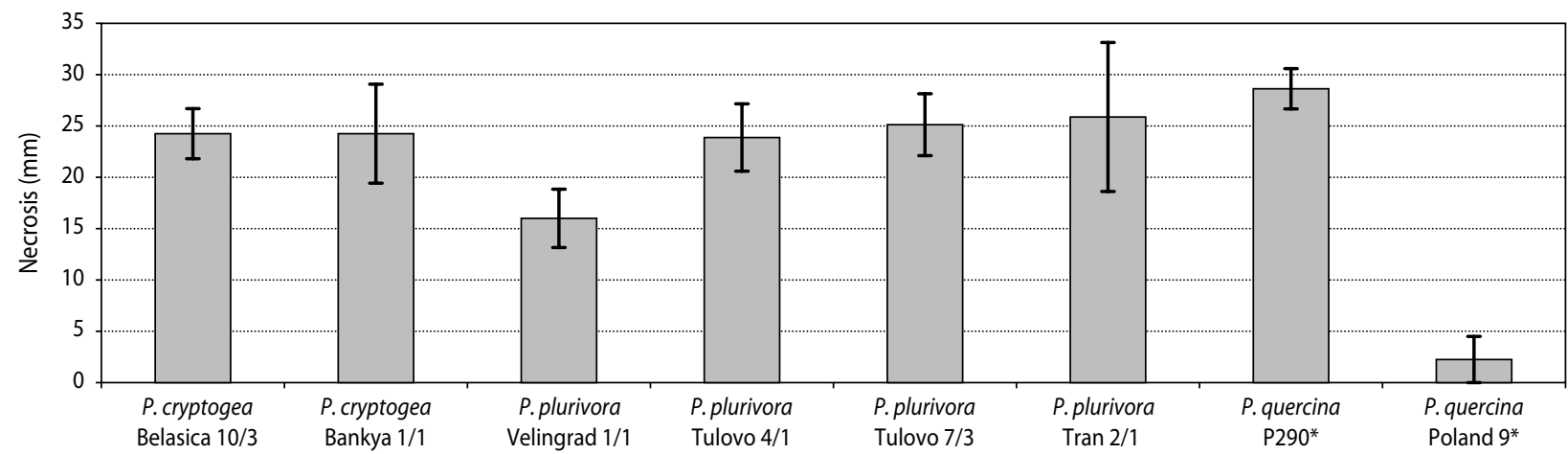

Phytophthora isolate

Figure 3. Mean length of necrosis caused by Phytophthora isolates on Turkey oak (Q. cerris) plants

* - statistically significant at $p=0.05$.

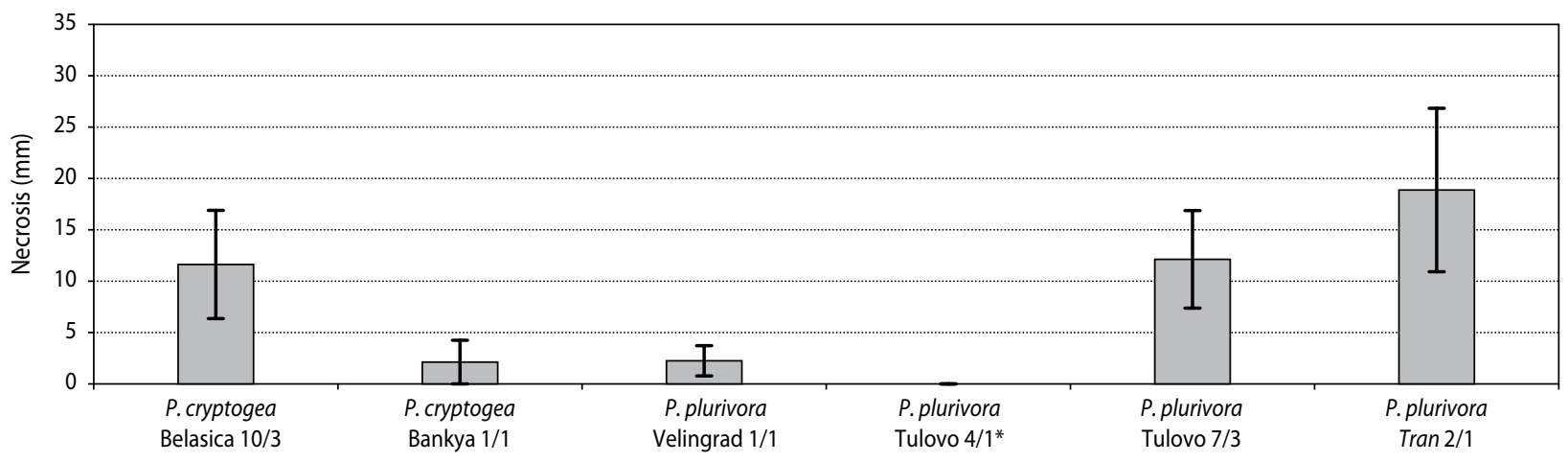

Phytophthora isolate

Figure 4. Mean length of necrosis caused by Phytophthora isolates on European beech (F. sylvatica) plants

* - statistically significant at $p=0.05$. 
to Q. cerris than to Polish Q. robur seedlings. In contrary, in the case of F. sylvatica inoculation (also Polish), both the isolates differed in their virulence level. The pathogen $P$. cryptogea Belasica 10/3 isolated from chestnut (broadleaved species) was more aggressive to beech than the pathogen P. cryptogea Bankya 1/1 isolated from spruce (conifer species). Also, both host plant species F. sylvatica and Q. robur of Polish origin were less susceptible to Bulgarian isolates of P. cryptogea in comparison to the Bulgarian host $Q$. cerris. It seems that aforementioned Phytophthora isolates are much better adapted to the Bulgarian oaks than to Polish host species (oak and beech), even though none were isolated from the tested plant host species. In this sense, it looks that tested Bulgarian isolates of $P$. cryptogea are potentially more hazardous to Bulgarian forests of $Q$. cerris than to Polish stands of English oak or European beech.

The reaction of English oak seedlings to the inoculation of $P$. plurivora is similar regardless of the isolate applied in the inoculation test. All oaks reacted by developing slight infection symptoms. Moreover, $P$. plurivora isolates expressed higher aggressiveness to Turkey oaks (Fig. 3). According to these findings, isolates of $P$. plurivora could have been expected to have smaller impacts in Poland (where English oak stands dominate) than in Bulgaria, where aforementioned pathogens could be recognised as very hazardous for Turkey oak stands. It is worth mentioning that all isolates of $P$. plurivora are pathogenic to both tested oak species, Q. robur from Poland and Q. cerris from Bulgaria, although two of them (Velingrad 1/1 and Tran 2/1) were isolated from alder (Tab. 1.). Four Bulgarian isolates of $P$. plurivora shown different level of aggressiveness to European beech (Fig. 4). Two of them are relatively highly virulent to $F$. sylvatica but the largest necrotic lesions are provoked by the isolate $P$. plurivora Tran 2/1, isolated actually from Alnus glutinosa host. Amongst all the tested $P$. plurivora isolates, the isolate Tran 2/1 seems to be the most hazardous one, infecting $F$. sylvatica and $Q$. cerris seedlings in a high level, and $Q$. robur plants in a medium level.

Both the isolates of $P$. quercina used in this study are isolated from $Q$. robur plants, one from Poland and the other from Germany. Interestingly, both aforementioned isolates did not infect Polish Q. robur seedlings in the performed pathogenicity tests. The isolate P. quercina Poland 9 originating from Poland did not infect Q. robur seedlings and slightly infected Q. cerris seedlings. On the contrary, the German isolate $P$. quercina P290 is very aggressive for $Q$. cerris but at the same time is not able to infect $Q$. robur plants.

\section{Discussion}

The inoculation experiment has revealed the pathogenicity of tested Phytophthora isolates, confirming the results from other similar studies (Weiland et al. 2010; Jankowiak et al. 2014). In our experiment, it was demonstrated that $P$. quercina can infect not only fine roots (Jung et al. 1999; Jönsson et al. 2003) but also tissues of Turkey oak stems. Also, most of the investigated isolates show the ability to grow in the living tissues without causing any visible disease symptoms. The successful re-isolations of pathogens from healthy looking tissues demonstrated their strategy to survive. The fact that these species seem to colonise plant tissues without causing symptoms is interesting, but would require more detailed investigation.

In this study, we demonstrated the potential pathogenicity of Phytophthora isolates originating from two different climate zones of European regions. All tested Phytophthora species appeared to be pathogenic to Turkey oaks, which could have disastrous consequences for the health of this important forest tree species, especially if climatic conditions become more favourable for the development of this pathogen.

The successful infection of F. sylvatica by $P$. plurivora could be considered as the lack of proper defence gene induction. Probably, P. plurivora escapes the plant-recognition systems (Schlink 2010). In future experiments, we should check if the noticed difference in isolates' pathogenicity to beech seedlings could be related to the mentioned mechanism of the pathogen recognition by plant cells.

Detection of $P$. plurivora is important because the species is known to be a pathogen with worldwide distribution, attacking several host plants, including European beech (Werres 1995; Fleischmann et al. 2005). This plant is a dominant tree species in most of the European forests, having high environmental and economic values. The beech decline phenomenon observed in European forests during the 1980s was also associated with the interaction between climatic weather extremes 
and $P$. plurivora damage caused to roots and butt collars of adult trees (Jung et al. 2000). In our study, we have shown that the Bulgarian isolates of $P$. plurivora, even if isolated from different host plants other than European beach, could be still potentially dangerous for $F$. sylvatica stands in Poland, if introduced and established in forest ecosystems.

The possible plant material for plantings or natural pathways of Polish and German P. quercina isolates to Bulgarian Turkey oak stands in the future may have different consequences for their health. Whilst the Polish isolate seems to have no significant impact, the German one seems to be so virulent that it can develop even in the stem tissue of oaks, which was not reported, so far. Therefore, in the case of its likely introduction to Bulgaria (sooner or later), it could have disastrous consequences for the forestry.

The oak-specific fine root plant pathogen P. querci$n a$ is a significant factor in the current phase of the European oak decline phenomenon with two subgroups were distinguished by Cooke et al. (2005), probably because of the initial introduction of isolates having different genetic backgrounds. The Polish strain of P. quercina (in contrast to the German one) did not show, under the conditions of our experiment, long lesions on Turkey oak stems, although P. quercina in Germany is considered to be the main driver of the English oak decline phenomenon, causing fatal damage to its fine roots (Jung et al. 1999). So far, according to Jung, P. quercina was only pathogenic to the roots and not to other plant tissues, but it is worth noting that in our experiment, the German isolate caused the most evident lesions (the longest necrosis, around $28 \mathrm{~mm}$ ) in stem tissues of Turkey oaks.

Jönsson (2006) suggested the link between the root damage caused by P. quercina and the overall tree vitality because of different allocation of carbon within the plants. The susceptibility of English oak to this pathogen has been hypothesised that it depends on the carbon availability in roots being an essential resource for the defence system (Angay et al. 2014). The concentrations of non-structural carbohydrates (NSC) in roots depended on the alternating root/shoot growth rhythm, being high during the root flush (RF) and low during the shoot flush (SF). The infection success in the above experiment was high during RF and low during SF, resulting in a significantly positive correlation between pathogen DNA and NSC concentration in roots (Angay et al. 2014). In our experiment, we did not measure the concentration of NSC but phenological observations suggest that our inoculations were performed during the SF phase, which can explain the lower than expected success of infection. In the monitoring of oak health, it is wise to take into account the alternating growth of roots and shoots, because this phenomenon plays a crucial role for the susceptibility of lateral roots to the soilborne pathogens. The availability of NSC in oak roots has to be considered as a benchmark for susceptibility rather than resistance against $P$. quercina.

The soil properties, especially, the $\mathrm{pH}\left[\mathrm{CaCl}_{2}\right]$ value higher than 3.5 and the distinct decrease in the groundwater level enhance the virulence of $P$. quercina - the root pathogen (Thomas 2008).

The pathogenicity of south-Swedish isolates of $P$. quercina in acid forest soils under restricted water availability was studied by Jönsson et al. (2003). They found that in the acid forest soil, the percentage of fineroot dieback was high. Stress-induced susceptibility of the seedlings and/or increased aggressiveness of the pathogen in the forest soil are discussed as key factors to explain the difference in root dieback between soil types. In our experiment, oaks grew in the optimal $\mathrm{pH}$ (5.5-6.5) and were regularly watered, so such conditions surely did not stress the plants and did not increase the potential aggressiveness of tested $P$. quercina isolates.

The alternative explanation could be related to the research performed by Cooke et al. (2005), who distinguished two subgroups of $P$. quercina isolates, and probably, it may also be reflected in their pathogenicity. They stated relatively low genetic diversity, probably because of the predominantly inbreeding (homothallic) nature of $P$. quercina. However, the evidence on limited intra-site diversity, temporal variation and the lack of clonality within the European population suggest that some diversity is being maintained by occasional outcrossing and turnover of a reservoir of long-lived soilborne oospore (sexually derived) inoculum (Cooke et al. 2005). Probably, the above fact can explain the difference in the virulence between Polish and German isolates observed in our experiment.

The connection of tested Phytophthora species to oak decline is beyond the scope of this manuscript because an inoculation experiment alone (with three tree species) cannot be attributed to decline events. How- 
ever, this assay helped us clarify to some extent the role of this group of pathogens as possible and potential contributors to the oak and beech decline phenomena in Europe. During this century, many European oak ecosystems (including the most valuable oak stands in Poland) have shown signs of stress and some have suffered periods of considerable decline and mortality (Oszako 1997; Basiewicz et al. 2007). Similar problems with oak health occurred in Bulgaria (Stefanov 1953). Many decline incidences showing typical symptoms for Phytophthora damage were recorded there.

However, the first recorded outbreak of oak decline took place in 1739-1748 (Thomas 2008). The suggested causes of European oak declines (apart from drought, winter cold and attacks by insects and fungi) may include root disease caused by the aggressive, exotic oomycete root pathogens belonging to Phytophthora genus (Jung et al. 1999, 2002; Jung and Nechwatal 2008), and therefore, in our experiment, we aimed to confirm it (or not) in the case of Polish and Bulgarian oaks. The significance of phytophthoras in Europeans forests is steadily rising, especially after the spectacular host jump of Phytophthora ramorum Werres, De Cock \& Man in't Veld, which is the cause of the Sudden Oak Death in United States and is now killing Japanese larch trees in United Kingdom (Brasier 1999). In the past decades, pathogens from Phytophthora genus are associated with several cases of decline in European forests, causing much concern amongst scientists (Oszako 1997; Jung et al. 1999, 2002). Introduced pathogen Phytophthora cinnamomi Rands was found to be involved in Mediterranean oak decline, whilst another phytophthoras were found in the rhizosphere of damaged ash trees across Europe (Orlikowski et al. 2011). Alarmingly, since 1993, a newly emerged lethal disease is killing alders along European rivers. It is caused by the natural hybrid species Phytophthora alni Brasier \& S.A. Kirk and is spreading across Europe (Brasier 1999).

Protecting plants from Phytophthora species is still a challenge. In the past decade, a large number of new species have been described beyond agriculture, which are known to cause enormous economic and environmental losses. The impact of exotic forest pathogens (in numbers of recognised species) on Mediterranean ecosystems becomes more severe every year (Garbelotto and Pautasso 2012; Santini et al. 2013). Under conditions of global warming, the survival and degree of root disease caused by this organisms seem likely to be enhanced and their host range might also expand (Nakova 2010; Orlikowski et al. 2011). Little is known about indigenous Phytophthora species in natural ecosystems but a diverse, trophically complex Phytophthora community is important in many forests. The number of described species has steadily increased, with a dramatic spike in recent years as new species have been split from old and new species have been discovered through exploration of new habitats (Hansen et al. 2012). The intercontinental movement and transplantation of infected plant material partially explains the appearance of new species in unexpected places. However, it is also likely that novel species arise as a result of the hybridisation and rapid evolution of introduced species under episodic selection pressures (Callaghan and Guest 2015). Hybrid progeny may possess equal or greater virulence than parent species, thereby posing an increasing risk to our natural environment and agricultural production systems. This assumption may trigger new threats posed by the introduction of plant pathogens into new environments (e.g. from Bulgaria to Poland or the other way around). The increasing trade in plants over the past decades will undoubtedly increase the risk of introducing alien species in countries where they are not yet present (Garbelotto and Pautasso 2012). Therefore, strict regulations of international trade exist particularly for harmful pathogenic organisms. The movement of plants and plant products resulting from human activity is now recognised as a major pathway for the spread of invasive alien species.

The majority of representatives from the Phytophthora genus are root rot agents, which in general are recognised as one of the key threats to European forests. The outcomes from several research projects, European COST Actions and conferences of the International Union of Forest Research Organizations (IUFRO) proved the threat posed by invasive pathogens (Santini et al. 2013). The large-scale analysis of Phytophthora infestations in Europe (Jung et al. 2015) has clearly demonstrated that the current international plant health protocols are outdated and seriously flawed. The existing phytosanitary system, despite of the European regulations posed by the European Commission (Directive 2000/29/EC), allows further introductions of potentially invasive Phytophthora pathogens to Europe (Jung et al. 2015). The new holistic and integrated systems 
approach is urgently required. The high interest in the pathway analysis and the commodity-oriented analysis approach is very welcome.

\section{Conclusion}

All tested isolates belonging to $P$. cryptogea, P. plurivora and $P$. quercina species turn out to be pathogenic to Turkey oaks (Quercus cerris) of Bulgarian origin. The isolates of P. cryptogea and P. plurivora, but not those of $P$. quercina, are pathogenic to English oaks (Q. robur) of Polish origin.

The Bulgarian isolates of P. cryptogea and P. plurivora differ in their pathogenicity to European beeches (F. sylvatica) of Polish origin. From all tested isolates, especially three (P. cryptogea Belasica $10 / 3$ isolated from Cannabis sativa, $P$. plurivora Tulovo $7 / 3$ isolated from $Q$. robur and $P$. plurivora Tran 2/1 isolated from A. glutinosa) caused significant damage to European beech plants.

The observed pathogenicity of Polish and Bulgarian Phytophthora species have demonstrated their potential as important contributors to the declined phenomena of tested tree species (F. sylvatica, Q. robur and Q. cerris) in valuable ecosystems in both countries.

\section{Acknowledgements}

We express our gratitude to COST Action FP0801 'Established and Emerging Phytophthora: Increasing Threats to Woodland and Forest Ecosystems' in Europe for providing a Short-Term Scientific Mission in IBL (Poland) to Aneta Lyubenova and to SEE-ERA.NET PLUS project PHYSEE/ERA 138 for the support during this work.

\section{References}

Angay O., Fleischmann F., Recht S., Herrmann S., Matyssek R., Osswald W., Buscot F., Grams T.E.E. 2014. Sweets for the foe-effects of nonstructural carbohydrates on the susceptibility of Quercus robur against Phytophthora quercina. New Phytologist, 203 (4), 1282-1290.
Basiewicz M., Jankiewicz D., Woodward S., Soulioti N., Oszako T. 2007. A review of historical data on selected alien invasive pathogens and pests in $\mathrm{Eu}-$ rope. In: Alien invasive species and international trade (eds.: H. Evans, T. Oszako), Forest Research Institute, Warsaw, Poland, 64-71.

Brasier C.M. 1999. Phytophthora pathogens of trees: their rising profile in Europe. Information Note, 30, $1-6$.

http://www.forestry.gov.uk/pdf/fcin30.pdf/\$FILE/ fcin30.pdf. Accessed 10 May 2016.

Callaghan S., Guest D. 2015. Globalisation, the founder effect, hybrid Phytophthora species and rapid evolution: new headaches for biosecurity. Australasian Plant Pathology, 44 (3), 255-262.

Cooke D.E.L., Jung T., Williams N.A., Schubert R., Osswald W., Duncan J.M. 2005. Genetic diversity of European populations of the oak fine root pathogen Phytophthora quercina. Forest Pathology, 35 (1), 57-70.

Fleischmann F., Koehl J., Portz R., Beltrame A.B., Osswald W. 2005. Physiological change of Fagus sylvatica seedlings infected with Phytophthora citricola and the contribution of its elicitin "Citricolin" to pathogenesis. Plant Biology, 7 (6), 650-658.

Garbelotto M., Pautasso M. 2012. Impacts of exotic forest pathogens on Mediterranean ecosystems: four case studies. European Journal of Plant Pathology, 133 (1), 101-116.

Hansen E.M., Reeser P.W., Sutton W. 2012. Phytophthora beyond agriculture. Annual Review of Phytopathology, 50, 359-378.

Ilieva E., Arulappan F.X., Pieters R. 1995. Phytophthora root and crown rot of raspberry in Bulgaria. European Journal of Plant Pathology, 101 (6), 623-626.

Jankowiak R., Stępniewska H. Bilański P. Kolařík M. 2014. Occurrence of Phytophthora plurivora and other Phytophthora species in oak forests of southern Poland and their association with site conditions and the health status of trees. Folia Microbiologica, 59 (6), 531-542.

Jönsson U. 2006. A conceptual model for the development of Phytophthora disease in Quercus robur. New Phytologist, 171 (1), 55-68.

Jönsson U., Jung T., Rosengren U., Nihlgård B., Sonesson K. 2003. Pathogenicity of Swedish isolates of 
Phytophthora quercina to Quercus robur in two different soils. New Phytologist, 158 (2), 355-364.

Jung T. 2009. Beech decline in Central Europe driven by the interaction between Phytophthora infections and climatic extremes. Forest Pathology, 39 (2), 73-94.

Jung T., Nechwatal J. 2008. Phytophthora gallica, sp.nov., a new species from rhizosphere soil of declining oak and reed stands in France and Germany. Mycological Research, 112 (10), 1195-1205.

Jung T., Cooke D.E.L., Blaschke H., Duncan J.M., Osswald W.1999. Phytophthora quercina sp. nov., causing root rot of European oaks. Mycological Research, 103 (7), 785-798.

Jung T., Blaschke H., Osswald W. 2000. Involvement of soilborne Phytophthora species in Central European oak decline and the effect of site factors on the disease. Plant Pathology, 49 (6), 706-718.

Jung T., Hansen E.M., Winton L., Osswald W., Delatour C. 2002. Three new species of Phytophthora from European oak forests. Mycological Research, 106 (4), 397-411.

Jung T., Orlikowski L., Henricot B., Abad-Campos P., Aday A.G., Aguín Casal O., Bakonyi J., Cacciola S.O., Cech T., Chavarriaga D., Corcobado T., Cravador A., Decourcelle T., Denton G., Diamandis S., Doğmuş-Lehtijärvi H.T., Franceschini A., Ginetti B., Glavendekić M., Hantula J., Hartmann G., Herrero M., Ivic D., Horta Jung M., Lilja A., Keca N., Kramarets V., Lyubenova A., Machado H., Magnano di San Lio G., Mansilla Vázquez P.J., Marçais B., Matsiakh I., Milenkovic I., Moricca S., Nagy Z.Á., Nechwatal J., Olsson C., Oszako T., Pane A., Paplomatas E.J., Pintos Varela C., Prospero S., Rial Martínez C., Rigling D., Robin C., Rytkönen A., Sánchez M.E., Sanz Ros A.V., Scanu B., Schlenzig A., Schumacher J., Slavov S., Solla A., Sousa E., Stenlid J., Talgø V., Tomic Z., Tsopelas P., Vannini A., Vettraino A.M., Wenneker M., Woodward S., Peréz-Sierra A. 2015. Widespread Phytophthora infestations in European nurseries put forest, seminatural and horticultural ecosystems at high risk of Phytophthora diseases. Forest Pathology, 46 (2), 134-163.

Lyubenova A., Kostov K., Tsvetkov I., Slavov S. 2016. Pathogens from the genus Phytophthora associated with fruit and forest species in Bulgaria (in Bulgar- ian with English summary). Forest Science, Sofia, 51 (1), 79-96.

Nakova M. 2010. Phytophthora root and crown rot on apples in Bulgaria. Pesticidi i fitomedicina, 25 (1), 43-50.

Orlikowski L.B., Gabarkiewicz R., Skrzypczak C. 1995. Phytophthora species in Polish ornamental nurseries. I. Isolation and identification of Phytophthora species. Phytopathologia Polonica, 21, 73-79.

Orlikowski L.B., Duda D., Szkuta G. 2004. Phytophthora citricola on European beech and silver fir in Polish forest nurseries. Journal of Plant Protection Research, 44 (1), 57-64.

Orlikowski L.B., Ptaszek M., Rodziewicz A., Nechwatal J., Thinggaard K., Jung T. 2011. Phytophthora root and collar rot of mature Fraxinus excelsior in forest stands in Poland and Denmark. Forest $\mathrm{Pa}$ thology, 41 (6), 510-519.

Oszako T. 1997. Oak decline in European forests. Bordeaux First EUFORGEN Meeting on Social Broadleaves (compil.: Turok J., Kremer A., de Vries S.) 23-25 October, 1997, IPGRI, Bordeaux, France, $145-151$.

Oszako T., Orlikowski L.B., Trzewik A. 2007. Menace to Polish forest nurseries by Phytophthora species. Progress in Plant Protection, 47 (2), 224-234.

Panov P., Bulgariev I. 1982. Problems of the common chestnut in Bulgaria. Ministry of Forests and Forest Industry (in Bulgarian), 18-22.

Santini A., Ghelardini L., De Pace C., Desprez-Loustau M.L., Capretti P., Chandelier A., Cech T., Chira D., Diamandis S., Gaitniekis T., Hantula J., Holdenrieder O., Jankovsky L., Jung T., Jurc D., Kirisits T., Kunca A., Lygis V., Malecka M., Marcais B., Schmitz S., Schumacher J., Solheim H., Solla A., Szabo I., Tsopelas P., Vannini A., Vettraino A.M., Webber J., Woodward S., Stenlid J. 2013. Biogeographical patterns and determinants of invasion by forest pathogens in Europe. New Phytologist, 197 (1), 238-250.

Schlink K. 2010. Down-regulation of defense genes and resource allocation into infected roots as factors for compatibility between Fagus sylvatica and Phytophthora citricola. Functional and Integrative Genomics, 10 (2), 253-264.

Schoebel C.N., Stewart J., Gruenwald N.J., Rigling D., Prospero S. 2014. Population history and pathways 
of spread of the plant pathogen Phytophthora plurivora. PLoS One, 9 (1), e85368. DOI: 10.1371/journal.pone.0085368.g001

Stefanov D. 1953. Oak decline in Bulgaria and actions to prevent it (in Bulgarian). Izvestiya na Biologitcheskiya Institut pri BAN.

Thomas F.M. 2008. Recent advances in cause-effect research on oak decline in Europe. CAB Reviews: Perspectives in Agriculture, Veterinary Science, Nutrition and Natural Resources, 3 (037), 1-12.

Trzewik A., Orlikowski L.B., Oszako T., Nowakowska J.A., Orlikowska T. 2015. The characterization of Phytophthora isolates obtained from diseased Alnus glutinosa in Poland. Baltic Forestry, 21 (1), 44-50.

Weiland J.E., Nelson A.H., Hudler G.W. 2010. Aggressiveness of Phytophthora cactorum, P. citricola I, and $P$. plurivora from European beech. Plant Disease, 94 (8), 1009-1014.

Werres S. 1995. Influence of the Phytophthora isolate and the seed source on the development of beech (Fagus sylvatica) seedling blight. European Journal of Plant Pathology, 25 (6/7), 381-390. 